\title{
PROSES DERIVASI DAN INFLEKSI DALAM BAHASA INDONESIA PADA BERITA KORAN JAWA POS RADAR JOMBANG EDISI JULI 2019
}

\author{
Fatimatuz Zuhro ${ }^{1}$ \\ Program Studi Pendidikan Bahasa dan Sastra Indonesia, Fakultas Ilmu Pendidikan, \\ Universitas Hasyim Asy'ari, ozaocha13@gmail.com
}

\begin{abstract}
Abstrak
Penelitian ini bertujuan untuk menganalisis tentang pembentukan kata derivasi dan infleksi dalam Bahasa Indonesia. Perlu adanya bukti yang konkrit untuk mengetahui keduanya, seperti berita dalam koran, majalah, dan bacaan lainnya. Hal tersebut dikarenakan proses derivasi dan infleksi akan dipahami dalam bentuk bacaan bukan hanya teori saja. Penelitian ini menggunakan metode kualitatif. Teknik pengumpulan datanya menggunakan studi pustaka. Adapun yang menjadi objek penelitian adalah proses derivasi dan infleksi, sedangkan subjek penelitiannya yaitu kolom berita di Koran Radar Jombang Jawa Pos pada edisi tertentu secara acak. Hasil penelitian didapatkan bahwa didalam Koran Radar Jombang didapatkan beberapa kata yang mengalami prposes derivasi dan infleksi.
\end{abstract}

Kata kunci : Derivasi, Infleksi

\section{Abstact}

This study aims to analyze the formation of words of derivation and inflection in Indonesian. Concrete evidence is needed to find out both, such as news in newspapers, magazines and other readings. That is because the process of derivation and inflection will be understood in the form of reading not just theory. This study uses a qualitative method. Data collection techniques using literature study. As for the object of research is the process of derivation and inflection, while the subject of research is the news column in the Radar Jombang Jawa Pos Newspaper in a particular edition randomly. The results showed that in the Radar Jombang Newspaper obtained several words that experienced the derivation and inflection.

Key Words: Derivation, Infleksion

\section{PENDAHULUAN}

Dalam bahasa Indonesia, kata linguistik bukan hanya berarti ilmu tentang bahasa, tetapi juga berarti bahasa itu sendiri, atau mengenai bahasa. Sebagai alat komunikasi manusia bahasa adalah satu sistem yang bersifat sistematis sekaligus sistemis. Yakni bahasa bukan sistemtunggal yang bisa berdiri sendiri, akan tetapi terdiri dari beberapa subsistem. Berupa fonologi, morfologi, sintaksis dan semantik. Fonologi membahas tentang bunyi, morfologi tentang kata,sintaksis tentang kalimat, sedangkan semantik tentang makna kalimat. Namun, yang perlu kita tingkatkan mulai bunyi-bunyi menjadi kata atau bentuk kata yang bisa dipahami oleh manusia.

Awalnya manusia hanya bisa menangkap apa yang mereka dengar, setelah itu mereka bisa mengucap huruf yang terbentuk dalam kata. Pola-pola kebahasaan yang bersifat mengatur, secara morfologis ada pada proses morfemis yang nama lainnya adalah 
Jurnal DISASTRI (Pendidikan Bahasa dan Sastra Indonesia)

Volume 2, Nomor 1, Maret 2020| P-ISSN : 2716-4112 | E-ISSN: 2722-3329

pembentukan kata, yang dikenal dengan derivasi dan infleksi.

Menurut Ramlan (2012: 21) morfologi ialah bagian dari ilmu bahasa yang membicarakan seluk beluk bentuk kata serta pengaruh perubahanperubahan bentuk kata terhadap golongan dan arti kata, atau dengan kata lain dapat dikatakan bahwa morfologi memepelajari seluk beluk bentuk kata serta fungsi perubahanperubahan bentuk kata itu, baik fungsi gramatik maupun fungsi sematik. Dalam kajian morfologi biasanya dibedakan adanya beberapa morfem berdasarkan kriteria tertentu, di antaranya morfem terikat dan morfem bebas. Morfem bebas adalah morfem yang tanpa kehadiran morfem lain dapat muncul dalam ujaran. Dalam bahasa Indonesia misalnya bentuk pukul, ambil, potong dan gali termasuk dalam morfem bebas.

Berdasarkan macam-macam morfem, terdapat juga proses morfologis dalam morfologi. Proses morfologis ialah pembentukan kata-kata dengan menghubungkan morfem yang satu dengan morfem yang lain atau yang sering diartikan sebagai proses penggabungan morfem-morfem menjadi kata. Bentuk yang terkecil ialah morfem, sedangkan yang terbesar ialah kata (Samsuri, 1994: 190). Salah satu proses dalam morfologi dikenal dengan istilah derivasi dan infkleksi. Infleksi merupakan proses morfologis yang melibatkan tataran sintaksis, bersifat sistematis, predictable, teratur, otomatis, bersifat konsisten, tidak mengubah identitas leksikal. Adapun derivasi secara sintaksis tidak dapat diramalkan, tidak otomatis, tidak sistemik, bersifat opsional/ sporadis, serta secara morfologis dapat mengubah identitas leksikal. Untuk bahasa Indonesia misalnya, proses morfologis infleksi dan derivasi tersebut akan memberikan sebuah penjelas tentang status leksikonnya, sehingga secara morfologis dapat diketahui pembentukan kata yang mana yang termasuk infleksi dan derivasi itu. Oleh karena itu, pada penelitian ini menganalisis tentang proses derivasi dan infleksi dengan objek Koran Radar Jombang Edisi Juli 2019.

\section{METODE PENELITIAN}

Penelitian ini menggunakan metode kualitatif. Bogdan dan Taylor (Moleong, 2002:3) mendefinisikan pendekatan kualitatif sebagai prosedur penelitian yang menghasilkan data deskriptif berupa kata- kata tertulis atau lisan dari orang-orang dan perilaku yang diamati.

Indikasi dari model penelitian ini yang membedakannya dengan penelitian jenis lainnya, antara lain:

1) adanya latar alamiah;

2) manusia sebagai alat atau instrumen;

3) metode kualitatif;

4) analisis data secara induktif;

5) teori dari dasar (grounded theory);

6) deskriptif;

7) lebih mementingkan proses dari pada hasil;

8) adanya batas yang ditentukan oleh fokus; 
Jurnal DISASTRI (Pendidikan Bahasa dan Sastra Indonesia)

Volume 2, Nomor 1, Maret 2020| P-ISSN : 2716-4112 | E-ISSN: 2722-3329

9) adanya kriteria khusus untuk keabsahan data;

10)desain yang bersifat sementara;

11)hasil penelitian dirundingkan dan disepakati

bersama.

Teknik pengumpulan data menggunakan teknik baca dan catat. Sedangkan teknik analisis data nalisis data penelitian ini akan dilakukan berdasarkan langkah-langkah berikut:

1. mereduksi data yang terdapat pada Koran Radar Jombang Edisi Juli 2019

2. mengenali proses derivasi dan infleksi pada Koran Radar Jombang Edisi Juli 2019.

3. menganalisis data sesuai dengan teori

4. menyimpulkan hasil analisis proses derivasi dan infleksi Koran Radar Jombang Edisi Juli 2019.

\section{PEMBAHASAN}

Derivasi adalah pembentukan kata yang dapat merubah kelas kata.Yang awalnya kata kerja menjadi kata benda, atau yang lainnya.Seperti beli dan pembeli.Kata "beli" adalah kata kerja, setelah mendapat imbuhan, jadilah kata "pembeli" yang menjadi kata benda.Sedangkan infleksi adalah pembentukan kata yang tidak merubah kelas kata, tapi menempatkat kata sesuai dengan kalimatnya.Misalnya pada contoh kata "beli" tadi, jika mendapat awalan meakan menjadi "membeli", mendapat awalan di- menjadi "dibeli". Kata beli akan tetap menjadi kata kerja, tapi bisa membolak-balikkan kalimat aktif menjadi pasif atau atau penempatan subjek yang berbeda-beda.

Bauer menyatakan bahwa derivasi adalah proses dalam ilmu fonologi yang menghasilkan morfem baru, sedangkan infleksi adalah proses morfologis yang hasilnya adalah bentuk-bentuk kata yang berbeda dari kata yang sama. Lebih lanjut Bauer menjelaskan bahwa pembentukan infleksional dapat diramalkan, sedangkan pembentukan derivasional tidak dapat diramalkan.

Ada juga menurut pendapat Verhaar ada dua bagian bawahan yang terpenting dalam sistem morfemis, adalah bagian yang berdasarkan derivasi dan golongan yang berdasarkan infleksi. Bagianinfleksi adalah daftar sistem yang terdiri atas bentuk-bentuk dari kata yang sama, sedangkan derivasi adalah daftar yang terdiri atas bentuk-bentuk kata yang tidak sama. Misalnya bentuk memakan dan dimakan merupakan dua bentuk (aktif dan pasif) dari kata yang sama, yaitu makan; sedangkan bentuk memakandan pemakan merupakan dua kata yang berbeda (verba dan nomina). Dengan kata lain, infleksi adalah proses morfemis yang diterapkan pada kata sebagai unsur leksikal yang sama, sedangkan derivasi adalah proses morfemis yang mengubah kelas katanya. Ia juga menjelaskan bahwa semua perubahan afiksasi yang melampaui identitas kata disebut derivasi, sedangkanyang mempertahankan identitas kata disebut infleksi. 
Jurnal DISASTRI (Pendidikan Bahasa dan Sastra Indonesia)

Volume 2, Nomor 1, Maret 2020| P-ISSN : 2716-4112 | E-ISSN: 2722-3329

Dalam kajian Baeurjuga, ditetapkan bahwa dalam ilmu morfologi ada cara tersendiri dalam menentukan sebuah afiksasi atau imbuhan dalam kata termasuk derivasi atau infleksi. Peneliti menggunakan teori tersebut pada analisis kata pada berita di Koran Jawa Pos Radar Jombang Brantas Raya tanggal 16 Juli 2019 bagian pendidikan yang berjudul "Disdikbud Jombang Pantau Pelaksanaan MPLS SMP".Dalam judul berita tersebut terdapat kata 'pelaksanaan'.Yang dapat dianalisis sebagai berikut.

Pada proses pertama, ia termasuk afiks secara derivasi karena kelas kata menjadi berubah. Yang awalnya kata kerja menjadi kata benda. Juga perubahan makna terjadi pada proses tersebut. Begitu juga pada proses kedua. Sedangkan pada proses ketiga dan keempat, terjadi afiks secara infleksional karena kata 'laksana' walaupun mendapat imbuhan tetap menjadi kata kerja dalam bentuk berbeda.

Teori-teori tersebut oleh Baeur dituliskan sebagai mana berikut.

1) Imbuhan pada infleksi selalu menampakkan makna yang dapat diprediksi dan teratur, sedangkan makna dari imbuhan pada derivasi tidak dapat diramalkan. Seperti imbuhan infleksi -s yang menunjukkan makna jamak dalam bahasa Inggris, pada bentuk kata friends, eggs, dan bags. Berbeda dengan perubahan makna secara derivasi pada bentuk -age dalamadvantage 'keuntungan', shortage 'kekurangan', dan bandage 'pembalut'.

2) Seperti jika imbuhan mengubah bentuk kata dasarnya, imbuhan atau afiks itu bersifat derivasional. Apabila afiks itu tidak mengubah bentuk kata dasarnya maka imbuhan kata itu merupakan infleksional.

1) Pada suatu kaidah umum, bahwa apabila dapat menambahkan imbuhan infleksi pada salah satu jenis kelas kata maka akan dapat pula ditambahkan pada yang lain. Seperti, imbuhan pada kata kerja, maka pada kata benda bisa juga.

\begin{tabular}{|c|c|c|c|c|c|}
\hline $\begin{array}{l}\mathrm{N} \\
\text { o. }\end{array}$ & $\begin{array}{l}\text { Asal } \\
\text { Kata }\end{array}$ & $\begin{array}{c}\text { Imb } \\
\text { uha } \\
\text { n }\end{array}$ & Hasil & $\begin{array}{c}\text { Kela } \\
\text { s } \\
\text { Kat } \\
\text { a }\end{array}$ & $\begin{array}{c}\text { Pemb } \\
\text { entuk } \\
\text { an } \\
\text { Kata }\end{array}$ \\
\hline 1. & $\begin{array}{l}\text { Laks } \\
\text { ana }\end{array}$ & $\begin{array}{l}\text { Pe- } \\
\text { dan } \\
\text {-an }\end{array}$ & $\begin{array}{l}\text { Pelaks } \\
\text { anaan }\end{array}$ & $\begin{array}{l}\text { Kat } \\
\text { a } \\
\text { ben } \\
\text { da }\end{array}$ & $\begin{array}{l}\text { Deriv } \\
\text { asi }\end{array}$ \\
\hline 2. & $\begin{array}{l}\text { Laks } \\
\text { ana }\end{array}$ & Pe- & $\begin{array}{l}\text { Pelaks } \\
\text { ana }\end{array}$ & $\begin{array}{l}\text { Kat } \\
\text { a } \\
\text { ben } \\
\text { da } \\
\end{array}$ & $\begin{array}{l}\text { Deriv } \\
\text { asi }\end{array}$ \\
\hline 3. & $\begin{array}{l}\text { Laks } \\
\text { ana }\end{array}$ & $\begin{array}{l}\text { Me- } \\
\text { dan } \\
\text {-an }\end{array}$ & $\begin{array}{l}\text { Melaks } \\
\text { anakan }\end{array}$ & $\begin{array}{l}\text { Kat } \\
\text { a } \\
\text { kerj } \\
\text { a }\end{array}$ & $\begin{array}{l}\text { Inflek } \\
\text { si }\end{array}$ \\
\hline 4. & $\begin{array}{l}\text { Laks } \\
\text { ana }\end{array}$ & $\begin{array}{l}\text { Di- } \\
\text { dan } \\
\text {-an }\end{array}$ & $\begin{array}{l}\text { Dilaks } \\
\text { anakan }\end{array}$ & $\begin{array}{l}\text { Kat } \\
\text { a } \\
\text { kerj } \\
\text { a }\end{array}$ & $\begin{array}{l}\text { Inflek } \\
\text { si }\end{array}$ \\
\hline
\end{tabular}

Namun yang terjadi pada proses deivasi justru sebaliknya. Imbuhan derivasional tidak dapat ditambahkan pada setiap anggota kelas yang bersangkutan. Dengan demikian, dapat ditentukan bahwa 
Jurnal DISASTRI (Pendidikan Bahasa dan Sastra Indonesia)

Volume 2, Nomor 1, Maret 2020| P-ISSN : 2716-4112 | E-ISSN: 2722-3329

pada imbuhan-imbuhan infleksional itu bersifat produktif, sedangkan imbuhan derivasional bersifat tidak produktif.

Menurut Subroto, setiap proses secara morfologi, sebuah afiks akan termasuk infleksi kalau di dalam suatu paradigma dapat diramalkan untuk menggantikan afiks infleksi lainnya.Dengan demikian, terdapat juga makna yang teratur secara gramatikal di dalam paradigma infleksi.Ciri-ciri yang demikian tidak terdapat pada susunan pada afiks derivasional. Verhaar (1978) juga menyatakan bentuk-bentuk kata seperti membuka, dibuka terbuka, kaubuka, dan bukalah adalah susunan afiks infleksional. Dengan anonim, bentuk-bentuk tersebut merupakan kata yang sama, yang berarti juga empunyai idetitas leksikal yang sama. Perbedaan bentuknya adalah berkenaan dengan modus kalimatnya.Maka begitulah, awalan me-, di-, ter, ku- dan kau- adalah infeksional.Kita bisa ambil contoh pada kata dasar 'pantau' pada judul berita tadi.

\begin{tabular}{|c|c|c|c|c|}
\hline $\begin{array}{c}\text { IMB } \\
\text { UHA } \\
\mathrm{N}\end{array}$ & $\begin{array}{l}\text { BENT } \\
\text { UK } 1\end{array}$ & $\begin{array}{l}\text { BENT } \\
\text { UK } 2\end{array}$ & $\begin{array}{c}\text { BENTU } \\
\text { K } 3\end{array}$ & JENIS \\
\hline & $\begin{array}{c}\text { Panta } \\
\text { u }\end{array}$ & $\begin{array}{c}\text { Panta } \\
\text { ui }\end{array}$ & $\begin{array}{c}\text { Pantau } \\
\text { kan }\end{array}$ & \multirow{5}{*}{$\begin{array}{l}\text { INFLEK } \\
\text { SIONAL }\end{array}$} \\
\hline Me- & $\begin{array}{c}\text { Mema } \\
\text { ntau }\end{array}$ & $\begin{array}{c}\text { Mem } \\
\text { antau } \\
\text { i }\end{array}$ & $\begin{array}{l}\text { Meman } \\
\text { taukan }\end{array}$ & \\
\hline di- & $\begin{array}{c}\text { Dipan } \\
\text { tau }\end{array}$ & $\begin{array}{c}\text { Dipan } \\
\text { taui }\end{array}$ & $\begin{array}{l}\text { Dipant } \\
\text { aukan }\end{array}$ & \\
\hline Kau- & $\begin{array}{c}\text { Kaupa } \\
\text { ntau }\end{array}$ & $\begin{array}{c}\text { Kaup } \\
\text { antai } \\
\mathrm{u}\end{array}$ & $\begin{array}{c}\text { Kaupa } \\
\text { ntauka } \\
\text { n }\end{array}$ & \\
\hline $\mathrm{Ku}-$ & Kupan & Kupa & Kupant & \\
\hline
\end{tabular}

\begin{tabular}{|c|c|c|c|c|}
\hline Ter- & $\begin{array}{c}\text { tau } \\
\text { Terpa } \\
\text { ntau }\end{array}$ & $\begin{array}{c}\text { ntaui } \\
\text { Terpa } \\
\text { ntaui }\end{array}$ & $\begin{array}{c}\text { Tukan } \\
\text { taukan } \\
\text { tanan }\end{array}$ & \\
\cline { 1 - 3 } Pe- & $\begin{array}{c}\text { Pema } \\
\text { ntau }\end{array}$ & - & - & \\
\cline { 1 - 2 } $\begin{array}{c}\text { Pe- } \\
\text { dan } \\
\text {-an }\end{array}$ & $\begin{array}{c}\text { Pema } \\
\text { ntaua } \\
\text { n }\end{array}$ & - & - & \multirow{2}{*}{ DERIVA } \\
SIONAL \\
-an & $\begin{array}{c}\text { Panta } \\
\text { uan }\end{array}$ & - & - & \\
\hline
\end{tabular}

Dalam menentukan proses derivasi infeksi dan dilakukan dengan perbandingan ada atau tidaknya perbedaan makna kata kerja yang ber afiks dan kata dasar yang ditunjukkan oleh perbedaan identitasnya. Afiksasi (imbuhan) atau reduplikasi (pengulangan kata) yang tidak mengubah makna kata adalah proses infleksi, dan afiksasi atau reduplikasi yang mengubah maknakata adalah proses derivasi.Proses infleksi dalam bahasa Indonesia meliputi afiksasi dan reduplikasi yang dipaparkan di bawah ini.

a) Imbuhan Infleksi Meng-, Di-, Klitik Ku, Dan Kau-

Afiksasi (imbuhan) meng-, di-, dan klitik ku-,kau- pada verba berobjek (transitif) tindakannyatidak mengubah makna kata, akan tetapi menurunkan bentuk kata sesuai dengan tuntutan sintaksis. Perhatikan kata KUPAS dan KUTIP secara infleksi dapat diturunkan 
Jurnal DISASTRI (Pendidikan Bahasa dan Sastra Indonesia)

Volume 2, Nomor 1, Maret 2020| P-ISSN : 2716-4112 | E-ISSN: 2722-3329

bentuk mengupas, dikupas, kukupas, kaukupas, dan mengutip, dikutip, kukutip, dan kaukutip. Pengimbuhan afiks meng- + KUPAS (verba transitif tindakan), mengupas (verba transitif tindakan aktif dalam bentuk formal), dan afiks meng- + KUPAS (verba transitif tindakan), mengupas (verba transitif tindakan aktif). Kemudian, imbuhan di- dan klitik ku-, kau- + KUPAS (verba transitif tindakan), dikupas, kukupas, dan kaukupas adalah bentuk verba pasif transitif

Untuk lebih jelasnya ,perhatikan paparan di bawah ini dari beberapa kalimat dalam berita Koran Jawa Pos tadi,. Yang terdapat pada alenia kedua dalam kalimat "Hari ini kami memantau kegiatan PLS".

\begin{tabular}{|l|l|l|}
\hline Leksem & PANTAU & $\begin{array}{l}\text { Verba } \\
\text { Tran } \\
\text { sitif } \\
\text { Tind } \\
\text { akan }\end{array}$ \\
\hline Kami & $\begin{array}{l}\text { Memantau } \\
\text { (kegiatan) }\end{array}$ & $\begin{array}{l}\text { Verba } \\
\text { Transitif } \\
\text { Tindakan } \\
\text { Aktif } \\
\text { Berbentuk } \\
\text { Formal }\end{array}$ \\
\hline Kegiatan & $\begin{array}{l}\text { Dipantau } \\
\text { (kami) }\end{array}$ & $\begin{array}{l}\text { Verba } \\
\text { Transitif } \\
\text { Tindakan } \\
\text { Pasif }\end{array}$ \\
\hline Kegiatan & $\begin{array}{l}\text { Kupantau } \\
\text { (adik) }\end{array}$ & $\begin{array}{l}\text { Verba } \\
\text { Transitif } \\
\text { Tindakan } \\
\text { Pasif }\end{array}$ \\
\hline & Kaupantau & $\begin{array}{l}\text { Verba } \\
\text { Transitif } \\
\text { Tindakan } \\
\text { Pasif }\end{array}$ \\
\hline
\end{tabular}

Dari paparan di atas, pengimbuhan afiks infleksi meng- merupakan tuntutan struktur sintaksis dalam bentuk formal, yakni subjek (kami) diletakkan pada posisi sebelum kata kerja (memantau) yang mengisi fungsi subjek dan objek (kegiatan) diletakkan pada posisi sesudah kata kerja (memantau) yang mengisi fungsi sebagai objek. Selanjutnya, afiks infleksi di- pada kata itu merupakan tuntutan struktur sintaksis, yaitu objek (kegiatan) diletakkan pada posisi sebelum kata kerja (dipantau). Dengan begitu, pengimbuhan afiks infleksi mengdan di- tidak akan merubah makna leksikal kata tersebut.

b) Reduplikasi Infleksi Bahasa Indonesia

Pada pembentukan kata juga tak luput dari reduplikasi atau pengulangan kata.Proses reduplikasi penuh (pengulangan kata penuh) pada verba transitif tindakan merupakan proses reduplikasi infleksi karena untuk menyatakan murni tindakan tanpa mengubah makna kata kerja tersebut. Prosesitu juga bisa terjadipada banyak verba transitif tindakan dan memiliki makna yang tetap, yakni pluralitas atau jamak. Dengan demikian, reduplikasi penuh pada infleksi ini adalah proses reduplikasi infleksi yang digunakan untuk menurunkan kata kerja reduplikasi transitiftindakan plural.

Hal itu terbukti dari contoh kalimat di bawah ini.

1) Hatta menendang-nendang kursi

2) Ocha menimang-nimang bayiku.

3) Denada menggedor-gedor pintu kamar. 
Jurnal DISASTRI (Pendidikan Bahasa dan Sastra Indonesia)

Volume 2, Nomor 1, Maret 2020| P-ISSN : 2716-4112 | E-ISSN: 2722-3329

Pada contoh kalimat di atas, fungsi predikat diisi kata kerja reduplikasi transitip yang menunjukkan tindakan jamak atau plural. (menendang-nendang, menimang-nimang, menggedor-gedor). Kata kerja reduplikasi transitip ini juga diturunkan dari proses reduplikasi penuh pada verba transitif tindakan menendang, menimang dan menggedor (dari kata TENDANG, TIMANG dan GEDOR). Hal ini menunjukkan bahwa pada verba reduplikasi transitip tindakan.menendang-nendang, menimang-nimang, menggedor-gedoyang terjadi adalah bentuk jamak dari kata tunggal yang berafiks itu. Yakni menendang, menimang dan menggedor.

\section{SIMPULAN}

\section{Dari empat pembahasan diatas dapat diketahui bahwa dalam pembentukan kata seacara derivasional dan infliksional menyangkut juga beberapa aspek dalam ilmu morfologi, mulai dari afiksasi, reduplikasi, dan juga proses morfoemis sehingga dapat menghasilkan bentuk kata yang dapat digunkan dalam kaidah-kaidah kata pada Bahasa Indonesia.}

Kata-kata dalam bahasa-bahasa berefleksi, seperti bahasa Arab, Bahasa Latin, dan Bahasa Sanskerta, untuk dapat digunakan di dalam kalimat harus disesuaikan dulu bentuknya dengan kategori-kategori gramatikal yang berlaku dalam bahasa itu. Alat yang digunakan untuk penyesuaian bentuk itu biasanya berupa afiks, yang mungkin berupa prefiks, infiks, dan sufiks, atau juga berupa modifikasi internal yakni perubahan yang terjadi dalam bentuk dasar itu.Kata berafiks itu kemudian bisa ditentukan termasuk derivasi atau infleksi.

Dalam menentukan proses
derivasiinfeksi dan dilakukan dengan
perbandingan ada atau tidaknya
perbedaan makna kata kerja yang ber
afiks dan kata dasar yang ditunjukkan
oleh perbedaan identitasnya. Afiksasi
(imbuhan) atau reduplikasi (pengulangan
kata) yang tidak mengubah makna kata
adalah proses infleksi, dan afiksasi atau
reduplikasi yang mengubah maknakata
adalah proses derivasi.Pada
pembentukan kata juga tak luput dari
reduplikasi atau pengulangan kata.

Proses reduplikasi penuh (pengulangan kata penuh) pada verba transitif tindakan merupakan proses reduplikasi infleksi karena untuk menyatakan murni tindakan tanpa mengubah makna kata kerja tersebut. Proses itu juga bisa terjadi pada banyak verba transitif tindakan dan memiliki makna yang tetap, yakni pluralitas atau jamak. Dengan demikian, reduplikasi penuh pada infleksi ini adalah proses reduplikasi infleksi yang digunakan untuk menurunkan kata kerja reduplikasi transitiftindakan plural (makna jamak).

\section{DAFTAR PUSTAKA}

Chaer, Abdul. 2014. Linguistik Umum Edisi Revis Cetakan Keempat. Jakarta. PT. RINEKA CIPTA.

Lexy J. Moleong. 2002. Metodologi Penelitian Kualitatif. Bandung: PT. Remaja Rosdakarya. 
Jurnal DISASTRI (Pendidikan Bahasa dan Sastra Indonesia)

Volume 2, Nomor 1, Maret 2020| P-ISSN : 2716-4112 | E-ISSN: 2722-3329

Ramlan, M. 2009. Morfologi Suatu Tinjauan

Deskriptif. Yogyakarta: C.V.

Karyono.

Samsuri. 1994. Analisis Bahasa. Jakarta: Erlangga.
Subroto, D. Edi, 1985b. "Infleksi dan Derivasi (Kemungkinan Penerapannya dalam Pemerian MorfologiBahasa Indonesia)".Yogyakarta:

Universitas Sarjanawiyata Taman Siswa. 